\title{
PENDIDIKAN NILAI KARAKTER BIMBINGAN DAN KONSELING DI LEMBAGA PEMBINAAN KHUSUS ANAK PONTIANAK
}

\author{
Riki Maulana $^{1}$, Eli Trisnowati ${ }^{2}$, Rustam $^{3}$, Novi Andriati ${ }^{4}$ \\ 1, 2,3,4 Program Studi Bimbingan dan Konseling Fakultas Ilmu Pendidikan dan Pengetahuan Sosial \\ IKIP-PGRI Pontianak, Jalan Ampera No. 88 Pontianak \\ 'e-mail: rikimaulana@gmail.com
}

\begin{abstract}
Abstrak
Tujuan dari pengabdian ini adalah: 1) Memberikan pengetahuan dan pemahaman kepada anak tentang pentingnya nilai karakter, 2) Menerapkan kepada anak nilainilai pendidikan karakter yang mencakup religius, nasionalis, integritas, mandiri dan gotong royong. Metode kegiatan menggunakan langkah-langkah: 1) Pesiapan, yaitu dengan cara survey di lapangan, 2) Kegiatan, dengan cara penanyangan slide materi dalam bentuk power point, 3) Pemutaran video tentang karakter, 4) Tanya jawab. Hasil kegiatan: 1) Seluruh anak mampu memahami materi yang diberikan dalam layanan klasikal, 2) Seluruh anak secara antusias dalam mengikuti kegiatan, kondisi ini dapat dilihat dari ketepatan waktu kehadiran hingga selesai kegiatan, dan banyaknya peserta yang bertanya serta terharu karena pemutaran video, 3) Masingmasing anak aktif dalam memberikan saran pada saat memberikan kesimpulan diakhir kegiatan.
\end{abstract}

Kata Kunci: Pendidikan, Nilai Karakter, Bimbingan dan Konseling.

\section{Abstract}

The objectives of this dedication are: 1) Providing knowledge and understanding to children about the importance of character values, 2) Applying to children the values of character education which include religious, nationalist, integrity, independent and mutual cooperation. The method of activities uses the following steps: 1) Preparing, ie by surveying in the field, 2) Activities, by displaying slide material in the form of power points, 3) Playing a video about characters, 4) Question and answer. The results of the activity: 1) All children are able to understand the material provided in classical services, 2) All children are enthusiastic in participating in the activity, this condition can be seen from the timeliness of attendance until the completion of the activity, and the many participants who ask questions and are moved by the video playback, 3 ) Each child is active in giving advice when giving conclusions at the end of the activity.

Keywords: Education, Character Value, Guidance and Counseling.

\section{PENDAHULUAN}

Pendidikan karakter merupakan sistem penanaman nilai-nilai karakter terhadap peserta didik yang meliputi komponen pengetahuan, kesadaran, kemauan dan tindakan untuk melaksanakan nilai-nilai tersebut baik terhadap Tuhan Yang Maha Esa, diri sendiri, lingkungan maupun kebangsaan. Pentingnya pendidikan karakter sesuai dengan UU No 20 Tahun 2003 tentang Sistem Pendidikan 
Nasional pada pasal 3 yang menyebutkan bahwa pendidikan nasional berfungsi mengembangkan kemampuan dan membentuk karakter serta peradaban bangsa yang bermartabat dalam rangka mencerdaskan kehidupan bangsa. Pendidikan tidak hanya menjadikan peserta didik menjadi pandai tetapi yang lebih penting dapat menciptakan nilai-nilai luhur atau karakter bangsa. Nilai-nilai pendidikan karakter meliputi : 1) Religius; beriman dan bertaqwa, bersih, toleransi, cinta lingkungan, 2) Nasionalis; cinta tanah air, semangat kebangsaan, menghargai kebhinekaan, 3) Integritas; kejujuran, keteladanan, kesantunan, cinta pada kebenaran, 4) Mandiri; kerja keras, kreatif, disiplin, berani, pembelajar, 5) Gotong royong; kerjasama, solidaritas, saling menolong, kekeluargaan (Kemdikbud, 2016: 2).

Melalui pelayanan $\mathrm{BK}$, informasi yang berkaitan tentang nilai-nilai pendidikan karakter perlu disampaikan kepada anak melalui bimbingan klasikal bidang bimbingan pribadi, belajar, sosial dan karir. Kemdikbud (2016: 61) menjelaskan bahwa "Bimbingan klasikal merupakan kegiatan layanan yang diberikan kepada sejumlah peserta didik/konseli dalam satu rombongan belajar dan dilaksanakan di kelas dalam bentuk tatap muka antara guru bimbingan dan konseling atau konselor dengan peserta didik/konseli”. Bimbingan klasikal merupakan salah satu strategi layanan dasar serta layanan peminatan dan perencanaan indivual pada komponen program bimbingan dan konseling. Bimbingan klasikal diberikan kepada semua anak/konseli dan bersifat pengembangan, pencegahan, dan pemeliharaan.

Berdasarkan definisi di atas, bahwa peranan guru bimbingan dan konseling sangat penting artinya dalam memberikan bantuan informasi dalam layanan bimbingan klasikal kepada anak sehingga dengan demikian anak mengetahui secara jelas tentang informasi mengembangkan nilai-nilai pendidikan karakter dalam kehidupan sehari-hari. Ini merupakan tugas guru bimbingan dan konseling untuk memberikan informasi melalui bimbingan klasikal kepada anak, khususnya di lembaga pembinaan khusus anak Pontianak. Sehingga nantinya anak tersebut mencapai kematangan gambaran dan sikap tentang kehidupan yang berkarakter secara emosional, sosial, intelektual dan ekonomi dengan nilai-nilai pendidikan 
karakter. Ini berarti informasi yang disampaikan konselor sangat penting artinya bagi anak karena dengan adanya informasi tersebut merupakan salah satu usaha untuk membantu anak mengembangkan nilai-nilai pendidikan karakter.

Observasi yang dilakukan di Lembaga Pembinaan Khusus Anak (LPKA), bimbingan klasikal tentang nilai-nilai pendidikan karakter sudah dilaksanakan oleh petugas disana, namun masih belum efekif dan efisien (dikarenakan waktu pemberian layanan BK belum terjadwal dengan baik). Sedangkan gambaran pendidikan karakter anak di lembaga pembinaan khusus anak Pontianak masih kurang, anak belum santun dalam berbicara, belum bisa bersosialisasi dengan baik kepada teman dan petugas, masih terdapat siswa yang emosional (sering marah dan sulit mengontrol emosinya). Untuk itu pentingnya pendidikan karakter diberikan kepada anak di LPKA, agar anak bisa melaksanakan ibadah sesuai dengan keyakinannya, tertib dalam segala hal, santun saat berbicara dengan petugas, mengerjakan tugas yang diberikan, bisa mengontrol emosinya dengan baik, serta saling tolong menolong dan mengumpulkan sumbangan sukarela saat ada yang tertimpa musibah.

Tujuan kegiatan ini adalah 1) Memberikan pengetahuan dan pemahaman kepada anak tentang pentingnya nilai karakter, 2) Menerapkan kepada anak nilainilai pendidikan karakter yang mencakup religius, nasionalis, integritas, mandiri dan gotong royong. Sasaran objek kegiatan ini adalah berbagai literatur kepustakaan yang mendukung pengembangan materi. Peserta PKM mengumpulkan berbagai literatur (buku, jurnal, dan lainnya) yang menunjang dalam merumuskan materi layanan informasi. Literatur yang telah dikumpulkan oleh masing-masing peserta dianalisis dan dipilah untuk dapat digunakan sebagai acuan dalam memberikan pendidikan nilai-nilai karakter di LPKA, sasaran subjek kegiatan adalah anak pembinaan di LPKA Pontianak, yang beralamat di jalan Adi Sucipto. Alasan dipilihnya LPKA sebagai tempat kegiatan, dikarenakan daerah tersebut belum mendapatkan bimbingan dan konseling dalam meningkatkan nilainilai karakter.

Kajian teori yang berkaitan dengan karakter yaitu: Yusuf (2009: 21) menjelaskan layanan penguasaan konten merupakan: Layanan bantuan kepada 
individu (sendiri-sendiri ataupun kelompok) untuk menguasai kemampuan ataupun kompetensi tertentu melalui kegiatan belajar. Kemampuan atau kompetensi yang dipelajari itu merupakan satu unit konten yang di dalamnya terkandung fakta dan data, konsep, proses, hukum dan aturan, nilai, persepsi, afeksi, sikap, dan tindakan yang terkait di dalamnya. Cicchetti, D. \& Cohen, D. J (2006: 40), Layanan penguasaan konten membantu individu menguasai aspekaspek konten membantu individu menguasai aspek-aspek konten tersebut secara tersinergikan. Dengan penguasaan konten, individu diharapkan mampu memenuhi kebutuhannya serta mengatasi masalah-masalah yang dialaminya.

Kemendikbud, (2013: 2), pendidikan karakter yaitu layanan bimbingan dan konseling yang membantu peserta didik menguasai konten tertentu, terutama kompetensi dan atau kebiasaan dalam melakukan, berbuat atau mengerjakan sesuatu yang berguna dalam kehidupan di sekolah/madrasah, keluarga, dan masyarakat sesuai dengan tuntutan kemajuan dan berkarakter cerdas yang terpuji, sesuai dengan potensi dan peminatan dirinya. Layanan penguasaan konten adalah layanan bantuan kepada individu (sendiri-sendiri ataupun dalam kelompok) untuk menguasai kemampuan atau kompetensi tertentu melalui kegiatan belajar Prayitno, (2012: 30). Layanan penguasaan konten harus terdapat suatu konten atau kemampuan atau kompetensi tertentu yang dibelajarkan kepada siswa dan diharapkan siswa mampu menguasai konten tersebut secara matang. Penguasaan konten ini perlu bagi individu untuk menambah wawasan dan pemahaman, mengarahkan penilaian dan sikap,menguasai cara-cara kebiasaan tertentu untuk memenuhi kebutuhannya dan mengatasi masalah-masalahnya. Kedua tujuan khusus penguasaan konten dapat dilihat pertama dari kepentingan individu atau klien mempelajarinya, dan kedua isi konten itu sendiri.

Sukardi (2008: 24) mendefinisikan layanan BK bagi anak adalah layanan bimbingan dan konseling yang memungkinkan siswa memahami dan mengembangkan sikap dan kebiasaan belajar yang baik, keterampilan dan materi belajar yang cocok dengan kecepatan dan kesulitan belajarnya, serta tuntutan kemampuan yang berguna dalam kehidupan sehari-hari. Tujuan dari pemberian 
layanan Penguasaan konten terbagi menjadi dua. Pertama tujuan umum layanan penguasaan konten adalah dikuasainya suatu konten tertentu.

\section{METODE}

Sasaran subjek kegiatan ini adalah anggota pelaksana kegiatan berkolaborasi dengan Guru Bimbingan dan Konseling yang diwadahi dalam Musyawarah Guru Bimbingan dan konseling (MGBK) SMA di Kabupaten Kubu Raya. Pelaksanaan pengabdian dilakukan dengan tiga tahapan, dimana tahap pertama merupakan tahap persiapan. Pada tahap ini kelompok pengabdi melakukan survey pendahuluan untuk melihat kondisi di lapangan mengenai pengembangan penguasaan konten yang telah dihasilkan oleh guru BK di Kabupaten Kubu Raya. Dalam tahap ini dicari permasalahan-permasalahan yang dihadapi oleh guru BK dalam meningkatkan kemampuan pengembangan layanan penguasaan konten. Tahap selanjutnya merupakan tahapan pelaksanaan kegiatan pengabdian. Dalam tahap ini pengabdi melakukan kegiatan pengembangan layanan BK dalam bentuk pelatihan membuat penguasaan konten.

Tahap yang terakhir adalah tahap evaluasi. Pada tahap ini dilakukan evaluasi atas hasil yang telah dicapai oleh peserta pelatihan. Masukan dan perbaikan lebih lanjut dapat dilakukan pada tahap ini. Evaluasi diberikan dengan mengumpulkan data yang diperoleh dari kegiatan pelatihan pembuatan penguasaan konten. Data diambil dengan menyimpulkan pemahaman guru-guru BK ketika diberikan makalah yang disampaikan dengan metode ceramah dan dilanjutkan dengan tanya jawab/diskusi, serta dari hasil pengembangan penguasaan konten yang berwujud karya ilmiah baik laporan penelitian tindakan bimbingan dan konseling maupun artikel ilmiah yang dihasilkan oleh guru BK sebagai hasil dari pelatihan. Indikator ketercapaian tujuan pengabdian adalah bahwa $80 \%$ guru-guru BK sudah memahami penguasaan konten, arti penting layanan, arti penting peningkatan kualitas dan kuantitas guru BK berbentuk laporan penelitian tindakan bimbingan dan konseling maupun artikel ilmiah di bidang pendidikan. 
Pelaksanaan kegiatan Pengabdian pada Masyarakat ini dikemas dengan menggunakan pendekatan workshop. Kegiatan dilakukan menggunakan metode ceramah, diskusi dan latihan. Adapun langkah-langkah dalam pelaksanaan kegiatan pengabdian ini adalah sebagai berikut: (1) Peserta pelatihan diberikan materi mengenai layanan penguasaan konten, (2) Peserta diberikan kesempatan untuk mendiskusikan materi yang telah diberikan. Kesempatan tanya jawab diberikan untuk memperjelas hal-hal yang masih menjadi keraguan, (3) Peserta berlatih untuk mengembangkan layanan penguasaan konten, (4) Peserta diberikan bimbingan pelaporan hasil penelitian layanan bimbingan dan konseling khususnya layanan penguasaan konten, (5) Hasil karya pengembangan layanan penguasaan konten dikumpulkan dan dianalisis untuk diberikan masukan dan perbaikan lebih lanjut.

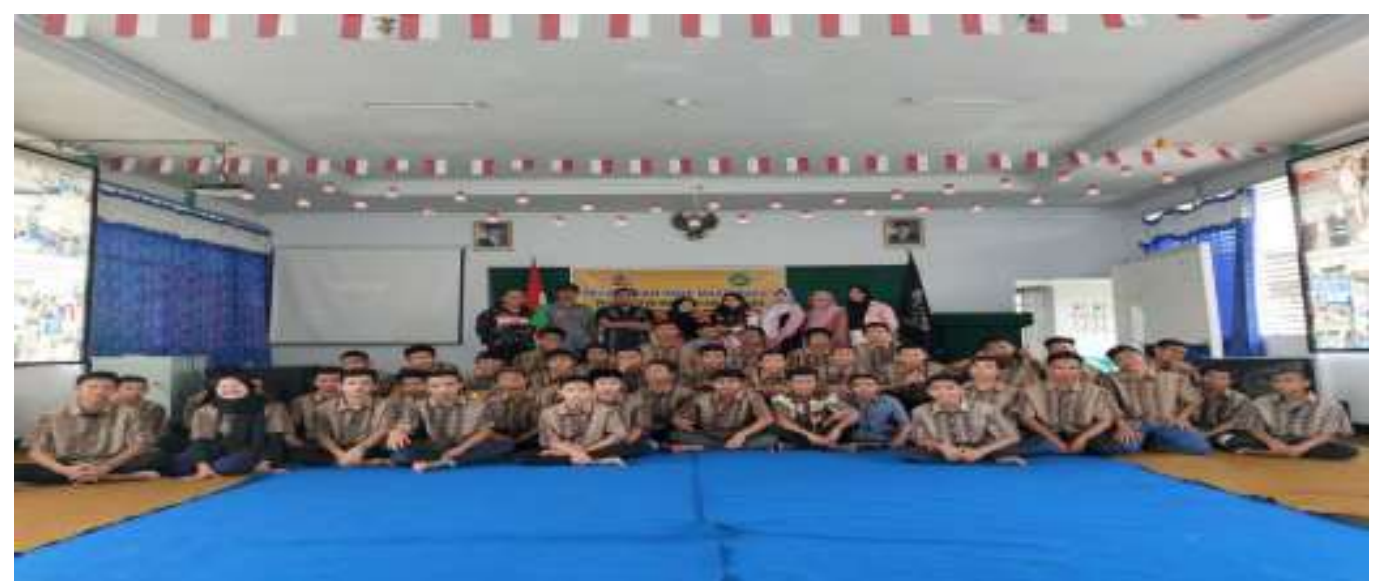

Gambar 1. Anggota Kegiatan

\section{HASIL DAN PEMBAHASAN}

Sebelum kegiatan inti dilaksanakan, peserta PKM mempersiapkan beberapa hal diantaranya sebagai berikut: (1) Merancang jadwal kegiatan, (2) menentukan jenis tempat dan tempat kegiatan, (3) Melakukan koordinasi dengan pihak terkait (fihak internal: anggota PKM dan fihak eksternal: Pegawai LPKA, (4) Menyusun kerangka kerja dan teknis pelaksanaan. (5) Membagi tugas kerja (job description) masing-masing anggota, (6) Mengumpulkan sumber atau materi sebagai kajian pustaka, dan (7) Merumuskan anggaran yang akan digunakan. Kegiatan dilaksanakan dalam bentuk layanan klasikal yang dilaksanakan di aula LPKA 
Pontianak, pada tanggal 1 September - 2 Oktober 2019. Anak binaan yang diberikan layanan berjumlah 60 anak, usia 13-17 tahun dengan kasus pidana yang berbeda-beda (pencurian, pembunuhan, asusila dan narkoba). Secara teknis pelaksanaan layanan bimbingan dan konseling tentang meningkatkan nilai-nilai karakter mencakup: 1) Kegiatan awal, (Salam doa, dan memperkenalkan diri), 2) Kegiatan inti, (Penyampaian materi menggunakan laptop dan infokus, pemutaran, video tentang karakter di rumah, sekolah dan masyarakat, tanya Jawab), 3) Kegiatan penutup, (Kesimpulan dari materi yang telah dipaparkan, doa salam).

Hasil Kegiatan: secara umum PKM Program Studi Bimbingan dan Konseling IKIP-PGRI Pontianak tahun akademik 2018-2019 dalam bentuk kegiatan pemberian layanan untuk meningkatkan nilai-nilai karakter di LPKA Pontianak berjalan dengan lancar. Tidak ditemukan kendala yang secara signifikan mempengaruhi tujuan dari kegiatan. Dari kegiatan tersebut, hasil yang dicapai sebagai berikut: 1) Seluruh anak mampu memahami materi yang diberikan dalam layanan klasikal, 2) Seluruh anak secara antusias dalam mengikuti kegiatan, kondisi ini dapat dilihat dari ketepatan waktu kehadiran hingga selesai kegiatan, dan banyaknya peserta yang bertanya serta terharu karena pemutaran video, 3) Masing-masing anak aktif dalam memberikan saran pada saat memberikan kesimpulan diakhir kegiatan.

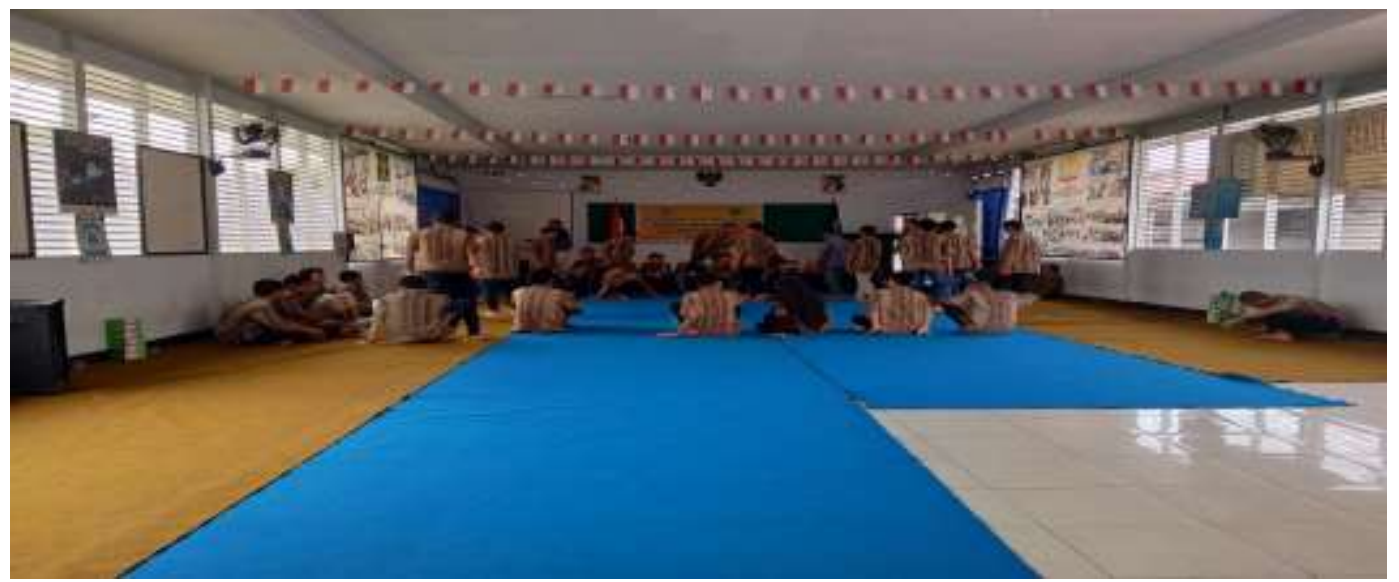

Gambar 2. Kegiatan PKM 
Penelitian relevan tentang pendidikan karakter: Mohammad, Y.G (2017), dengan judul Layanan Penguasaan Konten untuk Meningkatkan Keterampilan Berbicara di Depan Umum Bagi Siswa Kemampuan berbicara di depan umum adalah hal yang penting dimiliki oleh siswa untuk dapat berinteraksi. Hasil dari uji statistik disimpulkan bahwa terdapat perbedaan yang signifikan kemampuan berbicara di depan umum pada siswa kelompok eksperimen yang diberikan perlakuan layanan penguasaan konten, dengan siswa kelompok kontrol yang tidak diberikan perlakuan layanan penguasaan konten.

Sigit, H (2012), dengan judul Meningkatkan Motivasi Belajar dengan pembentukan karakter. Hasil penelitian terdapat perbedaan sebelum dan setelah diberikan layanan penguasaan konten dengan dukungan tampilan kepustakaan berbasis TIK. Sebelum diberikan layanan menunjukkan kategori sedang, dan sesudah diberikan perlakuan layanan menunjukkan kategori cukup tinggi. Peningkatan sebesar 10,53\% dengan ini dapat dikatakan bahwa motivasi belajar siswa SMA Negeri 2 Ungaran dapat dikatakan melalui layanan penguasaan konten dengan dukungan tampilan kepustakaan berbasis TIK.

Sartono (2014) dengan judul Peningkatan Tanggung Jawab Belajar Melalui Karakter dengan Teknik Role Playing. Hasil penelitian bahwa layanan penguasaan konten dengan teknik role playing dapat meningkatkan tanggungjawab belajar siswa, dapat dilihat hasil pengamatan pada pelaksanaan siklus I skor rata-rata yang diperoleh 2,4 dengan hasil pengamatan masih terdapat 5 siswa yang sedang dan 7 siswa yang rendah tanggungjawab belajarnya. Pada pelaksanaan siklus II terdapat perbaikan dengan cara anggota diminta menghayati baik secara perilaku maupun ucapan seperti layaknya pemain sinetron dalam layar TV dan scenario dari peneliti tanpa diberitahu, anggota diminta memainkan peran tersebut dengan baik. Pada siklus II ini pelaksanaan layanan penguasaan konten dengan teknik role playing dapat meningkatkan tanggungjawab belajar siswa, diperoleh hasil skor rata-rata yaitu 3,6.

Zamroni (2015) dengan judul Meningkatkan Kemandirian Belajar Melalui Layanan Penguasaan Konten dengan Teknik Latihan Saya Bertanggungjawab. Hasil penelitian layanan penguasaan konten dengan teknik latihan saya 
bertanggung jawab dapat meningkatkan kemandirian belajar siswa, dapat dilihat hasil pengamatan pada pelaksanaan siklus I skor rata-rata yang diperoleh 2,5 dengan hasil pengamatan masih terdapat 5 siswa yang sedang dan 6 siswa yang rendah tanggungjawab belajarnya. Pada pelaksanaan siklus II terdapat perbaikan dengan cara anggota diminta menyatakan kalimat saya bertanggung jawab untuk itu dengan kompak sambil mengepalkan tangan. Pada siklus II ini pelaksanaan layanan penguasaan konten dengan teknik latihan saya bertanggung jawab dapat meningkatkan.

\section{SIMPULAN}

Secara umum PKM Program Studi Bimbingan dan Konseling IKIP-PGRI Pontianak tahun akademik 2018-2019 dalam bentuk kegiatan pemberian layanan untuk meningkatkan nilai-nilai karakter di LPKA Pontianak berjalan dengan lancar. Saran: 1) Memberikan layanan informasi bimbingan dan konseling lanjutan tentang meningkatkan nilai karakter, 2) Membantu anak dalam beradaptasi dengan lingkungan LPKA, 3) Memotivasi anak untuk tidak terjerumus lagi dalam kasus yang telah dihadapinya, 4) Memberikan saran kepada anak untuk mempersiapkan diri setelah mereka keluar dari LPKA.

\section{UCAPAN TERIMA KASIH}

Terima kasih diucapkan kepada IKIP PGRI Pontianak atas dana Pengabdian kepada Masyarakat tahun anggaran 2019 yang diberikan, dan LPKA Pontianak.

\section{DAFTAR PUSTAKA}

Cicchetti, D. \& Cohen, D. J. (2006). Developmental psychopathology: theory and method. Canada: Wiley.

Kemendikbud. (2013). Peraturan mentri pendidikan dan kebudayaan no 81a. implementasi kurikulum 2013 lampiran IV. Jakarta: Kemendikbud.

Kemdikbud. (2016). Panduan operasional penyelenggaraan bimbingan dan konseling Sekolah Menengah Atas (SMA). Jakarta: Kementerian Pendidikan dan Kebudayaan Direktorat Jenderal Guru dan Tenaga Kependidikan.

Mohammad, Y.G. (2017). Layanan penguasaan konten untuk meningkatkan keterampilan berbicara di depan umum bagi siswa kemampuan berbicara di depan umum. Jurnal Fokus Konseling, 3 (2).

Prayitno. (2011). Pedoman khusus bimbingan dan konseling. Jakarta: Depdiknas. 
Prayitno. (2012). Jenis layanan dan kegiatan pendukung konseling. Padang: Universias Negeri Padang.

Ryan \& Bohlin. (2017). Pendidikan karakter. Yogyakarta: Pustaka Pelajar.

Sartono. (2014). Peningkatan tanggung jawab belajar melalui karakter dengan teknik role playing. Jurnal penelitian tindakan kelas, 16 (2): 32-37.

Sigit, H. (2017). Meningkatkan motivasi belajar dengan pembentukan karakter. Jurnal of guidane and counseling, 1 (1).

Sukardi. (2008). Pengantar pelaksanaan program bimbingan dan konseling di sekolah. Jakarta: Rineka Cipta.

Undang-Undang Republik Indonesia No.20 tahun 2003 tentang sistem pendidikan nasional. Jakarta: Kemendikbud.

Yusuf, S. (2009). Program bimbingan dan konseling di sekolah. Bandung: RIZQI Press.

Zamroni, N. (2015). Jurnal penelitian tindakan bimbingan dan konseling, 1 (1), Semarang: Didaktikum. 